Article

\title{
Retrotraction and the Young Leibniz's Critique of Hobbesian Sovereignty Notions
}

William F. Drischler

\begin{abstract}
Leibniz' 1669-1671 manuscript "Elements of Natural Right" - first published in the $21^{\text {st }}$ century - provides keen insights into problems of political philosophy and marks the outset of Leibniz' engagement with the Hobbesian indivisible sovereignty idea. While concurring with the Sage of Malmesbury that any state worthy of the name is a security system, Leibniz - via reversal of Hobbes' contention security produces happiness - throws open a series of questions related to "retrotraction" (retrotractio) and the state legitimacy problematic. Citizens' cognitive capacity to link current state crisis manifestations to past ones - to "retrotract" - is seen as determining whether dissolution of the state is immanent, and the functioning of such capacity is described as intimately linked to self-perceived happiness of individuals. The plurality of happiness possibilities in various polities in turn is conceptualized by Leibniz as proof of degrees of state quality and (ultimately) sovereignty, degrees of sovereignty constituting Hobbes' bête noire.
\end{abstract}

Key words: Leibniz, Hobbes, sovereignty, natural rights

\section{1}

The 2003 publication of Gottfried Wilhelm Leibni\%: Fruebe Scbriften zur Naturrecht by the Felix Meiner Verlag, a collection of material edited and translated by Hubertus Busche, ${ }^{1}$ was a milestone in the critical appropriation of the political and legal philosophy of the Hanoverian. An extraordinary selection of Latin-language materials with facing German translations permits modern language readers to enter Leibniz' intellectual workshop at the outset of his career in Mainz. The manuscript "Elements of Natural Right" (1669-1671) ${ }^{2}$ reveals the 23-year-old juris doctor as already engaged with the political philosophy of Hobbes, an engagement which was to continue through his magnum opus contra the Sage of Malmesbury - the Caeserinus Fuerstinerius of $1677^{3}$ - to his last major work, the Theodicy of $1712 .{ }^{4}$

1 Gottried Wilhelm Leibniz. Fruehe Schriften zur Naturrecht, ed. and trans, by and by Hubertus Busche (Hamburg: Felix Meiner Verlag, 2003). Hereinafter, GWL.FS $₹ N$.

${ }^{2}$ GWL.FS $2 N, 90-319$.

3 On Leibniz' Caesarinus Fuerstenerius of 1677, see Riley, Patrick, Ed., Leibniz. Political Writings (Cambridge, 1996), 111-120. 
Of particular interest in the "Elements of Natural Right" manuscript is a series of passages $^{5}$ which, as $\mathrm{H}$. Busche suggests, amounts to an outline for a systematic "philosophy of the state" (Staatsphilosophie). ${ }^{6}$ Utilizing his distinctive concept of retrotraction (retrotractio $)^{7}$ - i.e., the process wherein a knowing subject realizes an event he is experiencing is part of a longer historical chain and hence attains genuine understanding of the event at hand for the first time - Leibniz pulls together his six factors of the qualitative essence of the state with reference to a concrete (multiply-mediated) legitimation crisis analysis, arguing that just as happiness can only be said to exist as a self-conscious mental state, so the dissolution of a political state can only occur when a substantial portion of the citizenry actually perceives it as dissolving. The Hanoverian's delineation of levels of quality of states, this with regard to such considerations as consociative ("friendly") articulation of security structures, availability of goods, overall happiness of the citizens and presence of state will sufficiently unitary to govern - "will of the state" - sets the stage for the confrontation with Hobbes since the plurality of such quality levels strongly suggests varying degrees of sovereignty. Hobbes, it is contended, was concerned foremost with establishing indivisible unitary will of the state and yet the respective polities of Poland and the Holy Roman Empire of the German Nation display no such unitary will, i.e., emphatic sovereignty. If the degree of security (gradu securitas) $)^{8}$ - like other qualitative matters - varies widely in states which are persisting through time but is nonetheless indissolubly linked to sovereignty questions, then sovereignty cannot be an either/or proposition as Hobbes would have it. The Hanoverian goes so far as to indicate the possible viability of remedying the various imperfect (imperfectae) ${ }^{9}$ states - ones plagued by insufficient mutualistically-operating security structures to deliver goods and guarantee happiness - by means of rebellion, observing that old ruling structures "rarely" (raro $)^{10}$ change themselves (mutentur) ${ }^{11}$ using legal means. Following Hobbes however, as William Sweet has indicated, ${ }^{12}$ even the appearance of positive developments such as modern civil society would likely not be a licence to rebel, but rather an occasion for hosannas to indivisible sovereignty.

${ }^{4}$ Leibniz, G.W., Essais de Theodicee sur la bonte de Dieu, la liberte de l'homme et l'origine du mal (Paris: Flammarion, 1999). See also Maria Rosa Antognazza, Leibniq. An Intellectual Biography (Cambridge, 2009), 479-86.

5 GWL.FS 2 N , 159-164.

${ }^{6}$ GWL.FS $2 N, 456$, n. 85.

${ }^{7}$ GWL.FS $2 N, 160$.

${ }^{8}$ GWL.FS $2 N, 164$.

${ }^{9}$ Ibid.

10 Ibid.

${ }^{11}$ Ibid.

12 William Sweet, "Hobbes, Jaume et les droits inalienables." CARREFOUR 1991 31-2. A review of Lucien Jaume, Hobbes et l'etat representif modern. Collection "Philosophie d'aujourd'bui" (Paris: PUF, 1986). 
Although the Young Leibniz lacked Hobbes' monolithic focus on effectiveness of security structures as a basis to "grade" the state, the possibility that security problems could breed legitimate discontent or even rebellion is seen by the German as quite worthy of consideration. In the presence of allegedly multiple nexuses for conceivable legitimacy problems, i.e., nexuses both inside and outside security, Leibniz was only being systematic in outlining retrotraction dynamics as a means to integrate his six key factors of state essence. Such attention to the coming-to-consciousness of a legitimation crisis would likely have been foreign to the Sage of Malmesbury; Hobbes - owing to his experiences in the English civil war of the 1630s and 1640s - might well have quipped: when sovereignty breaks down, you'll know it.

\section{Gestation of the "Elements of Natural Right" Manuscript, 1669-1671}

Leibniz was promoted to the status of juris doctor at Altdorf on February 22, 1667 after the presentation of a dissertation prepared under the supervision of Johann Wolfgang Textor. ${ }^{13}$ The young scholar was promptly offered his choice of professorships at Altdorf in philosophy, Latin or law, but turned them all down, stating he had other things in mind, i.e., political affairs. In an episode which has never been fully clarified, the summer of 1667 found Leibniz in Nuernburg on the payroll of alchemists allegedly linked to the Rosecrucean sect. Between loans collateralized from his mother's estate and the fees earned administrating the alchemist society, sufficient funding for a West European Fall tour was assembled and by November the philosopher was in the Frankfurt-Mainz corridor striking up an acquaintanceship with Johann Christian v. Boineburg (1622-1672), chief secretary to Johann Phillip v. Schoenborn (1605-1673), the most influential elector of the Holy Roman Empire. As H. Busche relates, ${ }^{14}$ at this fortuitous juncture Boineburg and his chief legal counsel Hermann Andreas Lasser were embarking on the Great Mainz Law Reform project, one seeking to bring brevity and order out of the vast Corpus juris civilis. So far as Boineburg and Lasser were concerned, many of the jurists who had contributed to the Corpus were mere compilers, not philosophers, and a trained jurist who was concurrently trained in speculative philosophy was required to reduce the Corpus to short summaries of ready intelligibility. After a series of interviews the two Mainz officials found Leibniz sensationally well-qualified to work on the project, and on April 26, 1668 Boineburg wrote to his own mentor Hermann Conring that he perceived the young graduate to be a "highly-educated, excellent philosopher, of extraordinary endurance, capable of speculative thought constructs and decisive as well."15 As a foundation and introduction to the law reform project in its entirety, Leibniz drafted a compendium of natural right concepts under

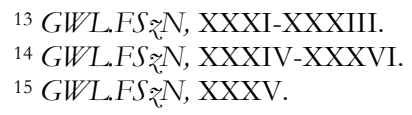


the title Elemente des Naturrechts between 1669 and 1671 - this is the nature of the manuscript published by $\mathrm{H}$. Busche in $2003^{16}$ which contains the excerpts on the philosophy of the state under review in this paper. They appear in Section 2, "Stringent Right, Justice and Piety" of the text.

\section{Retrotraction and the Rebuttal ofHobbesian-Voluntarist Sovereignty Notions by the Young Leibniz}

The retrotractive critique of the indivisible sovereignty doctrine in the "Elements of Natural Law" manuscript begins with reference to the split sovereignty structure of the post-1648 Reich, i.e., a sprawling governmental entity in Europe displaying no signs of a strongly unitary political order. "The Reich" - it is trenchantly observed - is really "a family of states" (familia civitandum), ${ }^{17}$ but one possessing an authority center "which the others obey" and hence ultimately constituting a single entity. Such is so far removed from a unitary political order however that it is best described as a "system of federated states" (systema civitatum foederatarum). ${ }^{18}$ How does the system hold together? It is a "pluralistic formation of entities which guarantee security for one another" (civitas multitudo formam habens praestantium sibi securitatem). ${ }^{19}$ Chief signs of successful mutual security guarantees include security system general articulation and a predictable legal framework for conducting affairs. Mere promises of delivering a "security order" won't suffice to create it, but - oddly enough - misperceptions as to the degree of security provided can be rather extensive without endangering the system. So long as the subjects do not "retrotract" unduly (connect local security problems historically with systemwide problems) "then it is not necessary that security be present factually [in the manner in which it has been claimed"]. ${ }^{20}$ Leibniz then summarizes political retrotraction by observing that "the state is not yet dissolved unless said dissolution is manifest to the public."21 A minority of the population can maintain the state, it is added, even if a substantial group claims to believe state dissolution has already taken place; the latter group can be ostracized as "enemies" (bostibus) 22 of the "great part" (magnae parti) 23 of the populace. Governing minority groups (i.e., particularlist German princes, princelings and minor estate members) need not assemble to exercise control, it is continued. "An assembly in one place is not necessary since nothing speaks against the assertion that the estates ... can constitute ... something to be called a state (vocem rempublicam)." 24 "The state is a collection of burgers that - via a

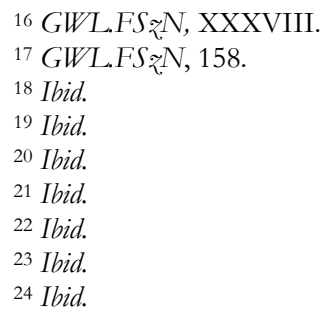


consolidated security form - has brought forth a structure of autarchy or preservation of happiness (felicitates)." 25

Thus far Leibniz has: (a) initially challenged voluntarist sovereignty doctrine by affirming the split-sovereignty character of the Reich; (b) contended that a functioning security order must in all cases guarantee a predictable legal order for ordinary affairs; (c) in contradistinction to Hobbes stressed the mediated (retrotracted) character of security anxiety for political subjects; (d) in contradistinction to much of indivisible sovereignty theory denied any kind of assembly or fixed governmental venue is required to conduct affairs; and (e) contended that a functioning public security system must guarantee not only its own autarchy but preserve happiness, the latter highly derivative from security from the Hobbesian perspective. Leibniz will now take the opposite position from that of the English philosopher and contend security is highly derivative from (calculations or perceptions concerning) happiness.

After describing the Reich as a pluralistic family, stressing the variety of estates capable of discharging state responsibility and introducing the subjectivistic category of happiness as a public function, it comes as little surprise when Leibniz next asserts there are qualitiative differences between states.

"There is no doubt (nibil dubitandum) ${ }^{26}$ (that some states are better and, it must be added, better-regulated - than others. This is indeed so because a state is a security society (Societas securitatis), ${ }^{27}$ that is, a plurality of people who conduct their affairs with the mutual expectation of providing for their security." 28 The philosopher then proceeds to provide a definition of security. "Security" - it is asserted - is the "improbability of unhappiness" (miseriae improbabilitas), i.e., the calculation and perception of subjects that they will likely be happy in the future. If this be true, then it can be revealed "from the peculiar essence of the state" 29 which six factors substantially modify a respective state's level of quality. These are: ${ }^{30}$

- $\quad$ Number of people (multitudine hominum)

- Character of individuals (hominibus)

- Quantum of distress or unhappiness (miseria)

- Perception of likelihood of distress or unhappiness (improbabilitate)

- $\quad$ Public opinion of the state (opinione)

- Durability of the structure (durabilitate)

${ }^{25} \mathrm{Ibid}$.
${ }^{26} \mathrm{GWL} . \mathrm{FS}$ ₹ָN, 160.
${ }^{27} \mathrm{Ibid}$.
${ }^{28} \mathrm{Ibid}$.
${ }^{29} \mathrm{Ibid}$.
${ }^{30} \mathrm{Ibid}$.


"The factors may look singular, but in fact they are deducted (derived) from one another" (Ac tamen singulis tum in se ductis), ${ }^{31}$ the philosopher further observes. "A state may be changed by numerous extrinsic (extrinsece) ${ }^{32}$ factors but only one [type of factor] is essential, namely that which impinges on the respective quantum and growth of the quality of life, that is, when people do not orient their expectations soley toward security but also toward higher goods in life." 33 Such a higher stage of expectations is seen as ultimately originating in "the best form of the state, one in which all live with an expectation of mutually guaranteed felicitous circumstances." 34 Is there a sharp correlation between the best constitutional form and the best state? "Form is what I call the most articulated constitution," 35 Leibniz goes on to say, but the best state is not seen as simply equivalent to the state possessing the best constitution. The best state:

$\ldots$ is that in which the citizens live in happiness. Those namely who are living in happiness live in the conviction that they are happy, because no one is happy who doesn't know about it. And further: he is happy who takes himself for happy so long as he is happy. ${ }^{36}$

Grounds for a potentially limited correlation between the best constitution and the best state, following Leibniz, include the status of retrotraction and legitimacy problems, areas which are - it is claimed - quasiautonomous vis-à-vis even the best form of constitution. "For the state it is a matter of indifference whether the citizens are truly or dubiously happy with the state of security within which they find themselves" 37 - ergo cognitive aspects of routinized citizen contentment count for little. But cognitive aspects of legitimation perceptions - the inflection of (especially) the opinione, improbabilitate and durabilitate state quality factors from the philosopher's sixfactor list - in significant part determine whether a state will exist or not. The state:

... does not actually dissolve itself - even if security has already been broken up - until public trust in security has been dissolved, even if the question presents itself as to whether retrotraction (retrotractio) is present, that is, the question of whether at the time of public perception of a

36 Ibid.

${ }^{37}$ Ibid. 
security matter the notion emerges that security has already been dissolved for a long time. ${ }^{38}$

And so we see Leibniz far removed from the unilinear indivisible sovereignty-security-happiness schema of Hobbes' Leviathan of 1651. Various degrees of sovereignty manifest themselves in different degrees of security and the relations of the first two are inflected with retrotraction phenomena which vary widely in historical context, according to the German. However - the analysis goes on to state - retrotraction phenomena come from somewhere, and a leading source is seen as imperfectio ${ }^{39}$ in the state form. Such imperfectio, such inability to preserve security, "can happen in two ways, when the state either has insufficient power (virium) or will (voluntatis) ${ }^{40}$ at hand". A state of perfected form is seen as clearly possible; however it must be equipped with power and decisive will. It must maintain itself:

... on the one hand on account of its power - so long as it does not reveal how it might readily dissolve itself - and on the other hand on account of its will to persist, this so long as it does not become public how much it lacks in spirit, will-power, decision-making capacity and above all its capacity to draw conclusions from events. Otherwise the state can rightfully be dissolved, something which takes place as soon as it no longer proclaims its will. Since there's no other assurance for security except decisive will to guarantee security - but there can be no decisive will when there is a plurality of wills - it is necessary for the state form that a single decisive will is extant, one that can be looked upon as the will of the state. ${ }^{41}$

Noteworthy in this definition is that retrotraction and legitimation problems appear once again, this time with reference to what might "become public" and cause the state to "rightfully be dissolved". But the philosopher appears to have created a novel imbroglio for himself in this instance since a single, decisive state will would seem to be quite similar to Hobbesian indivisible sovereignty, and so an explicit effort is undertaken to differentiate Leibniz' particularism from Hobbes's views. Such a decisive single will of the state, it is asserted, "is not, as the very learned Hobbes wanted, necessary in every state." 42 As was the case with Leibniz' rebuttal of Hobbes in the 1677 Caesarinus Fuerstinerius, Leibniz in 1669-1671 adopted a comparative legal systems approach, reminding the reading public that "If one only looks to Poland, one will find in this state no grounds to fervently hold on to unitary
38 Ibid.
39 GWL.FS $\approx N, 162$.
40 Ibid.
41 Ibid.
42 Ibid. 
agreement." 43 This is a reference to the notorious librum veto practice in the Sejm, the Polish legislature of the $17^{\text {th }}$ century. Librum veto was a unanimity requirement - one member of the body could veto anything, a fractured sovereignty convention which led to bitter divisions and governmental inertia even if Leibniz was to later implicitly praise the convention in the Caesarinus Fuerstenerius. In the Reich too - it is further observed - split sovereignty is found everywhere. Thus Hobbes' recommendations for the sovereign controlling selection of his successor - amidst other privileges - are seen as in no way binding for all Western political systems, in no respect constituting universalia ${ }^{44}$ The philosopher goes on to contend installation of a sovereign does not vitiate the citizens" "right to reconvene" (ius reconveniendi) ${ }^{45}$ to form new governmental bodies when old ones are ineffective. He is ready to concede states such as Poland are quite imperfectae and are in gradu securitatis inferior. ${ }^{46}$ That a king or senate of such a polity can force through a better security system without great evil is possible, it is concluded, but this with the caveat that older forms of rule are "seldom" (rarissime) ${ }^{47}$ legally modified. The apparent upshot of the Hobbes critique and the outline of security and sovereignty problems related to lack of decisive state will is that "will vacuum" may lead to retrotractive legitimacy problems which can dissolve a state, but that major states, e.g., $17^{\text {th }}$-century Poland and the Reich, have no such will but display durabilitate anyway.

\section{Conclusion}

The considerations on the nature of the state contained in Leibniz'1669-1671 manuscripts - produced in Mainz as an introduction to an ambitious reform of the legal system of the Holy Roman Empire and published in 2003 for the first time - are of signal importance. A variety of themes from Hobbes' Leviathan of 1651 - sovereignty, security, state quality and the preconditions for human happiness - are treated, in each case in a manner distinctive from that of the Sage of Malmesbury. In addition, what was to become the peculiarly German concept of "state will" (Staatswille) was analysed by the young philosopher and distinguished from the indivisible sovereignty notion. But likely most provocative of the ideas put forth was that of retrotraction, the cognitive process of linking an event to past ones, this an indispensable tool for analyzing legitimation crises and their potential to lead to state dissolution. Also of considerable interest was Leibniz' practice of reversing the order of happiness and security promulgated by Hobbes - the Englishman maintaining security guarantees happiness, the German claiming happiness guarantees security. Said Leibnizian position paved the way for outlining a six-factor analytic schema for evaluating the quality of states, a
43 Ibid.
${ }^{44}$ Ibid.
${ }^{45}$ Ibid.
${ }^{46}$ GWL.FS $₹$ N 164.
${ }^{47}$ Ibid. 
schema of potential use above and beyond the generation of new perspectives on legitimation problems.

Department of Philosophy, Dominican University College, Canada

\section{References}

Antognazza, Maria Rosa, Leibniz. An Intellectual Biography (Cambridge, 2009).

Jaume, Lucien, Hobbes et l'etat representif modern. Collection "Philosophie d'aujourd'bui" (Paris: PUF, 1986).

Leibniz, G.W.F., Essais de Theodicee sur la bonte de Dieu, la liberte de l'bomme et l'origine du mal (Paris: Flammarion, 1999).

, Gottried Wilhelm Leibniz. Fruebe Schriften zur Naturrecht, ed. and trans, by and by Hubertus Busche (Hamburg: Felix Meiner Verlag, 2003).

Riley, Patrick ed., Leibniz. Political Writings (Cambridge, 1996).

Sweet, William, "Hobbes, Jaume et les droits inalienables," in CARREFOUR, (1991). 